\title{
Magdalena Różycka
}

Wyższa Szkoła Turystyki i Ekologii w Suchej Beskidzkiej

\section{Anna Teler}

Uniwersytet Jagielloński

\section{ETYKA W ZARZĄDZANIU ORGANIZACJĄ MEDIALNĄ}

- NIEREALNE IDEAŁY CZY CELE?

WPŁYW PRZYWÓDCY NA ORGANIZACJĘ MEDIALNĄ.

TED TURNER I RUPERT MURDOCH - WYBRANE

ASPEKTY DZIAŁAŃ ZARZĄDCZYCH Z PERSPEKTYWY

ETYKI ZARZĄDCZEJ

Abstract

ETHICS IN THE MANAGEMENT OF MEDIA COMPANY - UNREALISTIC IDEAS OR REAL GOALS?

THE IMPACT OF MEDIA ORGANIZATION LEADERS. TED TURNER

AND RUPERT MURDOCH - SELECTED ASPECTS OF MANAGEMENT

FROM ETHICAL POINT

Business ethics are more than just words used to enhance the image of a corporation; they are the very foundation of success. Business ethics should be applied at the very moment of management.

Due to humanistic management, human is always a goal of every acting. The ethics of a business have the power to help or harm people. Business ethics are important because if an enterprise lacks ethics, the employees, the customers, and everyone else involved with the company can be harmed. This article summarises the findings from a study of practicing managers: Ted Turner and Rupert Murdoch, which explored experiences of and views on decision making about actual ethical issues in organizations. The analysis covers issues such as history of Ted Turner System and News Corp. organizations, developing mission, vision and value, strategy formulation, dilemma of a profitability, ethical and social responsibility and influence and role of manager in media organization. 
Postulating to instill ethics into decision making, creating vision and strategy in media management seems to be very universal.

Key words: media management, ethics, Ted Turner, Rupert Murdoch

\section{Wstęp}

Robert Picard formułuje pogląd, że media występują równolegle na dwóch rynkach, są zatem czymś, co autor określa jako dual product market (podwójny produkt rynkowy $)^{1}$. Dla rynku mediów podstawowe znaczenie ma wartość użytkowa, a więc zdolność do zaspokajania informacji i rozrywkowych potrzeb różnych kategorii odbiorców. Wartość użytkowa jest w podstawowym stopniu określana przez zawartość medium. Owa zawartość powstaje jako efekt pracy zbiorowej wielu osób reprezentujących bardzo różne specjalności. Drugi rynek, na którym media są obecne, to rynek reklamy mający dla mediów coraz większe znaczenie. Na rynku tym media oferują reklamodawcom swoją usługę polegającą na pośrednictwie w nawiązywaniu kontaktu między nimi a odbiorcami mediów². Od tej zdolności w istocie zależy sukces ekonomiczny organizacji medialnej. Ta charakterystyka rynku mediów ma zasadniczy wpływ na zarządzanie przedsiębiorstwami medialnymi.

Zarządzanie bywa definiowane jako proces planowania, organizowania, wpływania i kontrolowania po to, by osiągnąc cele organizacyjne poprzez skoordynowane użycie zasobów ludzkich i rzeczowych ${ }^{3}$. Jak wskazuje Bogusław Nierenberg, o wynikach przedsiębiorstwa decydują nie tylko zasoby kapitałowe i zaawansowane technologie, ale przede wszystkim doskonale przygotowany i ukierunkowany zespół pracowników ${ }^{4}$. Ważną cechą organizacji medialnych jest istnienie wielu specjalności zawodowych oraz znaczenie czynnika czasu dla zdobywania kwalifikacji przez doświadczenie ${ }^{5}$. Produkcja medialna charakteryzuje się znaczną intensywnością prac twórczych, a zarazem potrzebą dyscypliny realizacyjnej, co w rezultacie prowadzi do zaangażowania w produkcję wielu twórców i pracowników pomocniczych (kierowników produkcji, pracowników technicznych, administracji i reklamy). Stan ten wytwarza zmienne relacje między indywidualnymi pracownikami a organizacją ${ }^{6}$.

${ }_{1}^{1}$ R.G. Picard, Media Economics: Concepts and Issues, Sage Publications, Thousand Oaks, CA 1989, s. 17.

2 Tamże.

${ }^{3}$ R.W. Mondy, R.E. Holmes, E.B. Flippo, Management: Concepts and Practices, Allyn and Bacon, Boston 1983, s. 6.

${ }^{4}$ B. Nierenberg, Zarzadzanie mediami. Ujęcie systemowe, Wydawnictwo Uniwersytetu Jagiellońskiego, Kraków 2011, s. 39.

${ }_{5}^{5}$ A.K. Koźmiński, W. Piotrowski (red.), Zarządzanie. Teoria i praktyka, Wydawnictwo Naukowe PWN, Warszawa 1997, s. 363-369.

${ }^{6}$ M. Różycka, Zarzadzanie zasobami ludzkimi w mediach publicznych. Studium przypadku TVP Katowice, „Zarządzanie Mediami” 2016, t. 4, nr 2, s. 71. 
Kluczowym elementem twórczości medialnej są dziennikarze. Dziennikarstwo jako zawód twórczy wymaga kreatywnego rozwiązywania zadań, z drugiej jednak strony liczy się presja rynku i poszukiwanie za wszelką cenę wyższych słupków oglądalności, słuchalności czy sprzedaży. Dobrą ilustracją tej dychotomii był Ryszard Kapuściński, który podkreślał, że jest dziennikarzem, a nie pracownikiem mediów ${ }^{7}$.

Można uznać, iż wpływ mediów na funkcjonowanie współczesnych społeczeństw i świata polityki to „zdolność realna” - media nie tylko informują, lecz posiadają również siłę oddziaływania opiniotwórczego. Trudno wskazać sferę życia, w której nie byłyby one obecne, sprawując władzę „symboliczną". Media, jak zauważa Maciej Mrozowski, „nie są ani przezroczystym, ani neutralnym pośrednikiem komunikacji, tylko realizują swoje zadania "po swojemu", tzn. kierując się własną logiką i własnymi interesami"s. W ocenie Umberta Eco środki masowego przekazu nie tyle niosą ze sobą ideologię, ile same są ideologią. Konstatuje on, że: „nieważne, co będzie mówione przez kanały masowej komunikacji w momencie, w którym odbiorca bombardowany jest mnóstwem komunikatów, docierających do niego poprzez różne kanały równocześnie, natura tych informacji ma bowiem niewielkie znaczenie. Liczy się bombardowanie informacją, której treści przestają się różnić i wzajemnie się niwelują"9 . Autor wskazuje ponadto, że wszelka produkcja jest nastawiona na maksymalizację zysków, jak również na maksymalizację konsumpcji. Dlatego media masowe zwracają się ku masowemu odbiorcy.

W debatach poświęconych wpływowi mediów zbyt często zapomina się, że $\mathrm{z}$ jednej strony media stanowią źródło informacji, z drugiej zaś kształtują system wartości i postawy ludzi ${ }^{10}$. Jak słusznie zauważa Krystyna Czuba, media masowe powinny służyć społeczeństwu tak samo jak władza ${ }^{11}$, częściej jednak służą określonym grupom społecznym.

Można uznać, iż każda władza (również media, które sprawują władzę symboliczną i realną) powinna posługiwać się pewnym zbiorem wartości ontologicznych. Nikt nie przeczy, że wartości są czymś ważnym. Odwoływanie się do nich wydaje się tyleż nieuniknione, co niezbędne. Nie da się tego jednak czynić bez perswazji, że jedne wartości są święte, a inne nie, jedne uniwersalne, a inne partykularne, jedne nasze, a inne obce itd. Może za tym stać religia, polityka oparta na przesłankach bezwyznaniowych etc. Wszelako zawsze coś stoi, co przybiera kształt sporu politycznego, ekonomicznego, narodowościowego czy klasowego ${ }^{12}$. Tadeusz

7 B. Nierenberg, dz. cyt., s. 39.

${ }^{8}$ M. Mrozowski, Media masowe. Władza, rozrywka, biznes, Oficyna Wydawnicza ASPRA-JR, Warszawa 2001, s. 135.

9 U. Eco, Semiologia życia codziennego, przeł. P. Salwa, J. Ugniewska, Czytelnik, Warszawa 1999, s. 158.

${ }^{10}$ M. Karwat, O wymuszeniu medialnym, [w:] M. Duczmal, B. Nierenberg (red.), Media elektroniczne w procesie komunikacji rynkowej, Wydawnictwo Wyższej Szkoły Zarządzania i Administracji w Opolu, Opole 2005, s. 42.

${ }^{11}$ K. Czuba, Media i władza, Ad Astra, Warszawa 1995, s. 10.

12 Zob. www.humanizm.free.ngo.pl/wolenski2.htm (dostęp: 8.02.2017). 
Kotarbiński mawiał, że nigdy nie poważył się wykładać etyki (zwłaszcza normatywnej) z katedry uniwersyteckiej, bo zbyt to ważka sprawa, by popierać taki czy inny system moralny powagą profesora uniwersytetu głoszącego coś ex cathedra. Nie unikał jednak publicystyki moralnej, w której propagował małą aksjologię, pewne minimum przyzwoitości, które można uzasadnić elementarnym zmysłem moralnym ${ }^{13}$.

Bez względu na złożoność zagadnienia, jakim z pewnością jest etyka czy etyczne zachowania, „wymiar etyczny działalności gospodarczej to nie postulat pięknoduchów, jak myślą niektórzy prześmiewcy sprowadzający etykę do taniego moralizatorstwa. Jest to warunek autentycznej odpowiedzialności za podejmowane i wykonywane działania oraz ich skutki nie tylko krótko-, ale również długoterminowe"14.

Argumentem przemawiającym za obecnością etyki w zarządzaniu mediami jest fakt, że media pozostają „podstawowym źródłem wiedzy dla każdego człowieka i wywierają istotny wpływ na życie jednostek i całych społeczeństw"15. Media powinny być więc instytucjami zaufania publicznego. Można przyjąć, iż „samo zaistnienie w przestrzeni publicznej włącza konieczność stosowania etyki - bo społeczeństwo powstało i funkcjonuje dzięki regułom moralnym" ${ }^{16}$.

Media to ludzie tworzący przekazy - ale również ich szefowie (zarządzający organizacjami), którzy decydują o jakości i wiarygodności prezentowanych treści. Celem niniejszego artykułu jest wskazanie działań zarządczych w sektorze mediów. Skoncentruję się w nim na wybranych aspektach zarządzania przedsiębiorstwem medialnym w odniesieniu do postaci dwóch magnatów medialnych: Teda Turnera i Ruperta Murdocha. Szczególnie dużo uwagi poświęcę zagadnieniom sprzyjającym etyce, jak również tym, które stoją w sprzeczności z etycznym aspektem zarządzania. Podjęte badania skupiają się na społecznej i etycznej odpowiedzialności mediów, ale też na roli przywódcy w przedsiębiorstwie medialnym.

\section{Współczesne trendy w zarządzaniu mediami}

Zdaniem Petera F. Druckera: „naprawdę ważnymi wydarzeniami w świecie zewnętrznym nie są same trendy. Są nimi zmiany w tych trendach. To one w ostatecznym rozrachunku decydują o sukcesie bądź niepowodzeniu organizacji i jej wysiłków. Jednakże te zmiany trzeba po prostu dostrzec; nie można ich przeliczyć, zdefiniować bądź sklasyfikować” ${ }^{17}$. W opinii autora, „w czasach burzliwych

13 Tamże.

14 W. Gasparski, A. Lewicka-Strzałecka, I. Kuraszko, D. Bąk, B. Rok, Wolność czy swawola?, „Management and Business Administration. Central Europe” 2011, nr 19/5, s. 131.

15 J. Pleszczyński, Etyka dziennikarska i dziennikarstwa, Difin, Warszawa 2015, s. 39.

16 Tamże, s. 38.

17 P.F. Drucker, Menedżer skuteczny, przeł. J. Górski, J. Szyfter, Wydawnictwo MT Biznes Sp. z o.o., Warszawa 2004, s. 35. 
menedżerowie nie mogą zakładać, że dzień jutrzejszy będzie przedłużeniem dzisiejszego. Przeciwnie, muszą zarządzać z myślą o zmianach jako szansie i zagrożeniu"18.

Wydaje się, że wprowadzanie zmian i umiejętność zarządzania nimi to podstawowe zadania dla menedżerów zatrudnionych w mediach, zwłaszcza na stanowiskach kierowniczych ${ }^{19}$. Jest to „umiejętność dostosowywania się organizacji do permanentnie zmieniającego się, nieprzewidywalnego otoczenia" ${ }^{20}$. Uwzględniając odmienność branży medialnej, takie ujęcie elastyczności wydaje się najbardziej trafne.

Nie ulega wątpliwości, że środki masowej komunikacji medialnej w świecie współczesnym są mocno zrośnięte z systemem gospodarczym i politycznym państwa $^{21}$. To, co oferują, jest traktowane jak towar, którego cenę wyznacza popyt ${ }^{22}$. Jenna Cavallin pisze wręcz, że biznes nie służy demokracji ${ }^{23}$ oraz wolności i pluralizmowi mediów. Struktura własnościowa niewątpliwie oddziałuje na rolę mediów, rzutując na ich niezależność i pluralizm. Jak wskazuje Maciej Mrozowski, rynek mediów jest zainteresowany potrzebami o wymiarze publicznym jedynie wtedy, gdy wymaga tego ich interes ${ }^{24}$.

Wydaje się, że to właśnie wolny rynek coraz wyraźniej kształtuje oblicze mediów, w tym także moralną i profesjonalną kondycję współczesnego dziennikarza ${ }^{25}$. Typowa staje się pogoń za tanią, trywialną i często spreparowaną sensacją z jednej strony i zamierzone maskowanie nieuczciwych mechanizmów polityki z drugiej. O ile niegdyś dziennikarze zabiegali o prawdę, o tyle obecnie zabiegają głównie o tzw. newsa i oglądalność programu ${ }^{26}$. Zwrócił na to uwagę brytyjski premier Tony Blair, wskazując, że narastająca konkurencja zmusza media do uprawiania praktyk dziennikarskich, których celem jest uzyskanie maksymalnego efektu, na drugi plan spychając troskę o prawdę i zrównoważone przedstawienie faktów, a także oddzielenie informacji od opinii. Dążenie mediów, jak nazwał to Blair, do „niszczenia

18 P.F. Drucker, Zarządzanie w czasach burzliwych, przeł. J. Kajdy, Wydawnictwo Akademii Ekonomicznej, Kraków 1995, s. 47.

19 Tamże, s. 55.

${ }^{20}$ M.K. Gąsowska, Kluczowe wyzwania współczesnych menedżerów logistyki, „Przedsiębiorczość i Zarządzanie" 2013, t. 14, z. 12, cz. II, s. 390.

${ }^{21}$ A. Jaskiernia, Czynniki oddziałujace na zachowania mediów masowych w procesach wyborczych, [w:] M. Szpunar (red.), Media - między władzą a społeczeństwem, Wydawnictwo Wyższej Szkoły Informatyki i Zarządzania w Rzeszowie, Rzeszów 2007, s. 28.

22 S. Juszczyk, Człowiek w świecie elektronicznych mediów - szanse i zagrożenia, Wydawnictwo Uniwersytetu Śląskiego, Katowice 2000, s. 40.

${ }^{23}$ J. Cavallin, Democracy, Free Market, Human Rights, [w:] Wolne media dla Europy, Centrum Monitoringu i Wolności Prasy, Kraków 1993, s. 202.

${ }^{24}$ M. Mrozowski, dz. cyt., s. 135.

25 J. Załubski, Dziennikarz czy media-worker? Ewolucja zawodu, [w:] D. Piontek (red.), W kręgu mediów i polityki, Wydawnictwo Naukowe Uniwersytetu im. Adama Mickiewicza, Poznań 2003, s. 25.

${ }^{26}$ Tamże. 
ludzi i reputacji” osłabia pewność kraju, wiarę w siebie i jego instytucje, zmniejszając zdolność do podejmowania właściwych decyzji ${ }^{27}$.

Branża medialna to biznes, w którym liczą się zyski ${ }^{28}$. Skutkuje to tym, że „dobro odbiorcy i szacunek do preferowanych przez niego wartości schodzą na dalszy plan - najważniejsza jest liczba widzów"29, słuchaczy, czytelników, internautów, czyli odbiorców dóbr medialnych, zaś najbardziej pożądanym rezultatem działań zarządczych jest osiąganie wzrostu ${ }^{30}$.

Rynek mediów podlega nieustannym zmianom. Potrzeby konsumentów zmuszają media do zachowań, dzięki którym mogą przetrwać na konkurencyjnym ryn$\mathrm{ku}$. Wydawcy i nadawcy medialni funkcjonujący na rynku często podejmują działania związane z dywersyfikacją działalności medialnej, inwestując m.in. w Internet. Henry Jenkins, dyrektor Programu Komparatystyki Mediów w Massachusetts Institute of Technology, nazywany McLuhanem XXI wieku, sformułował następujący pogląd: „dzisiaj nie mówimy już o rewolucji cyfrowej, która przewidywała, że stare media zostaną zastąpione nowymi. Teraz mówimy o konwergencji mediów, gdzie stare i nowe media wchodzą w coraz bardziej skomplikowane interakcje. Gdzie każda opowieść, marka, dźwięk, obraz, relacja znajdzie odzwierciedlenie w maksymalnej liczbie kanałów i platform medialnych"31. Oprócz powyższego stwierdzenia Jenkins interpretuje konwergencję jako „przepływ treści pomiędzy różnymi platformami medialnymi, współpracę różnych przemysłów medialnych oraz migracyjne zachowania odbiorców mediów, którzy dotrą niemal wszędzie, poszukując takiej rozrywki, na jaką mają ochotę. Konwergencja to termin charakteryzujący zmiany, jakie zachodzą w technice, przemyśle, kulturze i społeczeństwie" ${ }^{32}$. Innymi słowy, konwergencja jako proces „znosi granice pomiędzy mediami, nawet w bezpośredniej komunikacji, takiej jak poczta, telefon, telegraf, i komunikacji masowej, takiej jak prasa, radio i telewizja" ${ }^{33}$. Z kolei Jan Kreft, powołując się na Fredrika Hacklina, widzi w konwergencji możliwość „dostarczania przez różne sieci podobnego rodzaju usług lub występowania razem różnego rodzaju urządzeń, takich jak telefon, telewizja i komputery osobiste, lub (...) wspólne występowanie oddzielnych wcześniej produktów wykorzystujących cyfrowe technologie"34.

27 T. Blair, Lecture by the Prime Minister the Right Honourable Tony Blair, MP, on Public Life, Reuters, Canary Wharf, London 2007.

${ }_{28}$ T. Kowalski, Między twórczościq a biznesem. Wprowadzenie do zarządzania w mediach i rozrywce, Wydawnictwa Akademickie i Profesjonalne, Warszawa 2008, s. 48.

${ }^{29}$ M. Łobacz, Telewizja - szanse i zagrożenia wychowawcze, Maternus Media, Tychy 2007, s. 33.

30 T. Kowalski, dz. cyt., s. 48.

${ }^{31}$ H. Jenkins, Kultura konwergencji. Zderzenie starych i nowych mediów, przeł. M. Bernatowicz, M. Filiciak, Wydawnictwa Akademickie i Profesjonalne, Warszawa 2007, s. VII.

${ }^{32}$ Tamże, s. 9.

${ }^{33} \mathrm{~J}$. Kreft, Multimedia jako cel strategii konwergencji mediów - środowiska komunikacji w biznesie, www.jankreft.pl/pdf/artykuly/Multimedia\%20jako\%20cel\%20strategii\%20konwergencji\%20mediow.pdf (dostęp: 6.09.2017).

${ }^{34}$ Tamże. 
Reasumując powyższe rozważania, można stwierdzić, że aby zdobyć przewagę na konkurencyjnym rynku, nieodzowne jest podejmowanie świadomej aktywności biznesowej z równoczesnym uwzględnieniem wielu czynników i aspektów, takich jak elastyczność, dbałość o personel i odbiorcę. Okazuje się również, że niezwykle ważna jest perspektywa długofalowa, a także troska o szeroko rozumiane dobro ogółu, tzw. interes społeczny. Obowiązek troski o odbiorcę wynika ze specyfiki zarządzania mediami. W literaturze przedmiotu przeważa pogląd, iż „media bez względu na ich charakter i nośniki mają do spełnienia dwie funkcje: misję społeczną i komercyjną" ${ }^{35}$. Troska o dobro społeczne jest szczególnym elementem, wyróżniającym tę branżę na tle innych.

\section{Etyka w zarządzaniu}

Etyka to dziedzina filozofii, która zajmuje się badaniem moralności, czyli analizuje to, co leży u podstaw nakazów moralnych, oraz to, jakie skutki wywołują takie nakazy $^{36}$. Jeszcze do niedawna „czasowy i przestrzenny zakres refleksji etycznej był stosunkowo ograniczony. O etyce mówiło się w związku z działaniami na niewielką skalę związanymi z formami interakcji bezpośredniej. Świat etyki składał się z teraźniejszości i z jednostek usytuowanych tu i teraz, a etyczna refleksja miała charakter moralnego zbliżenia/bliskości" ${ }^{37}$.

„Etyka jako proces doskonalenia relacji między ludźmi analizuje dobro, zło, słuszność, obowiązki, odpowiedzialność, sprawiedliwość, wspólne dobro, wyższe dobro, godność, szczęście. Zarówno przywództwo, jak i etyka dotyczą relacji między ludźmi. Problemy i wyzwania przywództwa są jednocześnie problemami i wyzwaniami etyki, związane są z interesem własnym i altruizmem, racjonalnością i emocjami, samodyscypliną, powinnością oraz dobrem wspólnym"38. W istocie każde z tych stwierdzeń dotyczy współczesnego rynku mediów.

O etyce mówi się wielokrotnie w kontekście zawodu i nie ulega wątpliwości, że „etyka zawodowa ma wyraźnie charakter mieszany - teoretyczno-praktyczny. $\mathrm{Z}$ jednej strony wyznaczona jest zasadami etyki ogólnej, z drugiej zaś strony jest praktycznym przedłużeniem i sprawdzianem teorii” ${ }^{39}$. Punktem odniesienia dla

35 B. Nierenberg, dz. cyt., s. 81.

${ }^{36}$ Zob. http://www.focus.pl/artykul/czym-sie-rozni-etyka-od-moralnosci (dostęp: 22.12.2017).

${ }^{37}$ J.B. Thompson, Media i nowoczesność. Społeczna teoria mediów, przeł. I. Mielnik, Astrum, Wrocław 2006, s. 254.

${ }^{38}$ I. Kuraszko, Etyka przywództwa: dlaczego, jak i gdzie idziemy?, [w:] I. Kuraszko (red.), Etyka przywództwa. Ujęcie interdyscyplinarne, Difin, Warszawa 2014, s. 20.

${ }^{39}$ J.W. Gałkowski, Zasady etyki zawodowej - etyka biznesu, [w:] M. Borkowska, J.W. Gałkowski (red.), Etyka w biznesie, Towarzystwo Naukowe Katolickiego Uniwersytetu Lubelskiego, Lublin 2002, s. 20-21. 
etyki zawodowej - w tym etyki mediów, biznesu, dziennikarstwa i innych - jest etyka ogólna i łączy je respektowanie tych samych wartości i norm ${ }^{40}$.

W ramach etyki zawodowej, zdaniem Jana Pleszczyńskiego, etyka mediów i etyka dziennikarska często nie są dostatecznie rozróżniane. Bo chociaż „media, dziennikarstwo i dziennikarze to naczynia połączone, są to jednak naczynia różne". Konieczne jest podkreślenie, że etyka mediów i etyka dziennikarska są czymś innym względem siebie - „dziennikarz niepełniący funkcji kierowniczych w redakcji (a tacy stanowią przytłaczającą większość) nie ma żadnego wpływu, albo bardzo znikomy, na działania medium, w którym pracuje"41. Etyka mediów jest pojęciem szerszym niż etyka dziennikarska i „wchodzi w rozmaite relacje $\mathrm{z}$ wieloma innymi etykami szczegółowymi: etyką dziennikarską, reklamy, biznesu czy tzw. etyką publiczności"

Dlaczego etyka mediów jest tak istotna? Zdaniem autora „w naszym kręgu cywilizacyjnym przed mediami nie ma ucieczki. Media są podstawowym źródłem wiedzy dla każdego człowieka i wywierają istotny wpływ na życie jednostek i całych społeczeństw. Nie można także zapomnieć o wpływie mediów na więzi międzyludzkie; ludzi często łączy albo dzieli to, z jakich mediów korzystają. Media na-

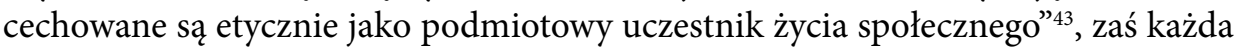
aktywność w obszarze społecznym ,jest prezentacją pewnej etyki i podlega ocenie wedle jakiejś etyki" ${ }^{44}$.

Etyczna refleksja nad zarządzaniem ma często charakter ogólniejszej myśli nad sensem i wartością podejmowanych decyzji oraz działań z nich wynikających ${ }^{45}$. Podejście to objawia się już na poziomie postaw jednostkowych, gdyż „na współczesnych menedżerach spoczywa zadanie współtworzenia etycznego klimatu dla swoich pracowników, tzn. takiego, w którym mogliby efektywnie pracować, mając do czynienia z możliwie jasnymi granicami między postępowaniem dobrym i złym" ${ }^{46}$.

Można przyjąć, że indywidualne cechy przywódcze nie są najważniejsze. Roli przywódcy nie należy jednak bagatelizować - „przywódcy wywierają bowiem wpływ na sposób działania innych pracowników i całego przedsiębiorstwa. Istotny pozostaje fakt, jak sprawić, by ten wpływ, szczególnie w wymiarze etycznym, był jak najbardziej pozytywny" ${ }^{37}$.

40 Tamże, s. 21.

${ }^{41}$ J. Pleszczyński, Różne rodzaje odpowiedzialności we wspótczesnych mediach, [w:] K. Wolny-Zmorzyński, M. Wrońska, W. Furman (red.), Między odpowiedzialnością a sensacją. Dziennikarstwo i edukacja na przełomie wieków, Wydawnictwo Uniwersytetu Rzeszowskiego, Rzeszów 2006, s. 111.

${ }^{42}$ J. Pleszczyński, Etyka dziennikarska i dziennikarstwa, Difin, Warszawa 2015, s. 40.

43 Tamże, s. 39.

44 Tamże, s. 38.

45 Tamże, s. 20.

${ }^{46}$ W. Misztal, Etyczny wymiar relacji międzyludzkich, [w:] K. Markiewicz, M. Wawer (red.), Problemy społeczne we wspótczesnych organizacjach, Difin, Warszawa 2005, s. 290.

47 Tamże, s. 190-191. 
Wojciech Gasparski podkreśla, iż: „doświadczeni specjaliści z zakresu etyki biznesu zwracają uwagę na to, że autentyczne zaangażowanie zespołu pracowników w kwestie etyczności firmy i kultury pracy nie powinno mieć charakteru przypadkowego, lecz stanowić pochodną udziału najwyższego kierownictwa w projektowaniu programu etycznego korporacji. Istotne są tu wola i zaangażowanie kierownictwa w tworzenie systemu wspierającego kształtowanie etycznej substancji organizacji”"48. Jest to o tyle ważne, że praca osób zarządzających „polega na codziennych kontaktach $\mathrm{z}$ innymi, tworzeniu i integrowaniu zespołów, motywowaniu i rozwijaniu zdolności pracowników, współpracy z innymi interesariuszami, kształtowaniu kultury organizacyjnej, postaw i zachowań ludzi, rozliczaniu i ocenianiu pracy, rozwiązywaniu konfliktów. Aby dobrze wykonywać te wszystkie zadania, trzeba być profesjonalistą"49.

Monika Kostera i Andrzej K. Koźmiński ostrzegają przed sztucznym izolowaniem etyki i eliminowaniem jej z rozważań o zarządzaniu: „Mówi się często o władzy jako samodzielnym zjawisku - i o trosce o innych, byciu w emocjonalnej relacji do innych jako o zjawisku osobnym od władzy" ${ }^{50}$. W ich ocenie ,jedna relacja nie istnieje bez drugiej; obie występują (jednocześnie) tam, gdzie ludzie wspólnie działają"51.

Można więc uznać, że etyczny zarządzający determinuje obecność etyki w przedsiębiorstwie medialnym. Zarządzający i każda inna osoba „propagująca wartości etyczne musi spełniać te kryteria, do których stosowania zachęca innych. Jest to szczególny przypadek, w którym pozycja eksperta nie wynika tylko z jego wiedzy, ale również jednoznacznej postawy. (...) W przypadku osób propagujących wysokie standardy etyczne nie wystarczy rzeczowość argumentacji czy sprawność erudycyjna, jeżeli nie uzyska to potwierdzenia w ich postępowaniu" ${ }^{2}$. Punktem odniesienia powinna być tu etyka Immanuela Kanta: „kierownik naprawdę moralny będzie wtedy, gdy źródłem jego poczucia obowiązku będzie jego wolna wola, nie zaś zewnętrzna presja prawa i obyczaju, pracodawcy lub środowiska" ${ }^{53}$.

${ }^{48}$ W. Gasparski, Kodeksy i programy etyczne, [w:] W. Gasparski (red.), Biznes, etyka, odpowiedzialność, Wydawnictwo Naukowe PWN, Warszawa 2012, s. 236.

49 T. Oleksyn, Zarządzający i zarządzanie - wybrane kwestie i dylematy etyczne, [w:] K. Kietliński, V. Martinez Reyes, T. Oleksyn (red.), Etyka w biznesie i zarzadzaniu, Oficyna Ekonomiczna Oddział Polskich Wydawnictw Profesjonalnych, Kraków 2005, s. 164.

${ }^{50}$ M. Kostera, A.K. Koźmiński, Wartości i normy w zarządzaniu. Cztery teatry, [w:] J. Dietl, W. Gasparski (red.), Etyka biznesu, Wydawnictwo Wyższej Szkoły Przedsiębiorczości i Zarządzania im. L. Koźmińskiego, Warszawa 2002, s. 192.

51 Tamże.

${ }^{52}$ W. Gasparski, A. Lewicka-Strzałecka, I. Kuraszko, D. Bąk, B. Rok, dz. cyt., s. 146.

53 Tamże, s. 184. 


\section{Ted Turner i Rupert Murdoch: zarządzanie etyczne - marzenia czy realne cele?}

Twórcą CNN był Ted Turner. Założył on również TBS (Turner Broadcasting System), TNT, Cartoon Network, Turner Classic Movies ${ }^{54}$. Główna siedziba CNN znajduje się w Stanach Zjednoczonych w Atlancie ${ }^{55}$. Pierwszy przekaz telewizyjny stacji odbył się 1 czerwca 1980 roku. Można uznać, że to właśnie wtedy „nastąpiło trzęsienie ziemi w amerykańskich magazynach wiadomości. Cable News Network, oglądany w pierwszych dniach przez ponad 15 milionów Amerykanów i telewidzów na całym świecie, był tak skonstruowanym 24-godzinnym programem, by widz chciał oglądać stację i cały jej program, nie zaś poszczególne audycje" ${ }^{\prime 6}$. Aby sprostać całodobowemu nadawaniu, miejsce pracy dziennikarzy i ludzi mediów, czyli newsroom, był czynny 24 godziny na dobę przez siedem dni w tygodniu. Pracowało w nim średnio 100 dziennikarzy, a w czasie ważnych wydarzeń nawet dwa razy tyle ${ }^{57}$. Nieznany dotąd $\mathrm{w}$ świecie mediów całodobowy charakter pracy spowodował podział newsroomu na trzy sekcje: zbieranie informacji, redagowanie, obróbkę treści i przygotowywanie materiałów filmowych ${ }^{58}$.

Warto zaznaczyć, że Ted Turner początkowo nie dysponował znaczącymi środkami finansowymi. Ponadto nie przeprowadził badań ani wywiadów fokusowych, nie słuchał też opinii, że stacja nadająca wiadomości przez całą dobę nie przyjmie się. Z perspektywy czasu okazało się, iż to on miał rację, zaś analitycy rynku mediów pomylili się. Im więcej informacji dostarczało CNN, tym większe było na nie zapotrzebowanie ${ }^{59}$.

„CNN zrewolucjonizowała dotychczasowe źródła wiadomości, rzesza korespondentów rozsianych po całym świecie zapewniała nie tylko łatwość i szybkość dostępu do informacji z pierwszej ręki. Powodowała ponadto, że dzięki nadmiarowi informacji realizatorzy zaczęli odczuwać przyjemność w daniu widzom szansy szybkiego przemieszczania się między odległymi kulturowo, politycznie i geograficznie miejscami. CNN dysponowała najlepszym sprzętem - była jedyną stacją, która na żywo przekazała rozpad promu kosmicznego Challenger w 1986 roku. $\mathrm{CNN}$, nieustannie rywalizująca $\mathrm{z}$ wielką trójką amerykańskich superstacji, była pierwsza w relacjach z placu Tian'anmen, jak i moskiewskiego puczu"60. Jak wskazuje Wiesław Godzic: „W wojnie nad Zatoką Perską w 1990 roku niewątpliwym

${ }_{54}$ J. Olędzki, Komunikowanie w świecie, Oficyna Wydawnicza ASPRA-JR, Warszawa 2001, s. 71.

55 Tamże.

${ }^{56}$ W. Godzic, Telewizja - najważniejsze medium XX wieku, [w:] W. Godzic (red.), Media audiowizualne. Podręcznik akademicki, Wydawnictwa Akademickie i Profesjonalne, Warszawa 2010, s. 80.

${ }^{57}$ J. Olędzki, dz. cyt., s. 72.

58 Tamże.

${ }_{59}$ M. Dacko, Wielkie fiasko. Fuzja AOL $i$ Time Warner. Studium przypadku, Wydawnictwa Akademickie i Profesjonalne, Warszawa 2007, s. 72.

${ }^{60}$ W. Godzic, dz. cyt., s. 80. 
zwycięzcą na polu informacji okazał się właśnie Ted Turner, którego dziennikarze relacjonowali zdarzenia $\mathrm{z}$ obu stron frontu. Nigdy żadna służba sprawozdawcza nie odegrała tak wielkiej roli w informowaniu świata o lokalnym konflikcie zbrojnym" ${ }^{61}$. Największym atutem stacji były - i nadal są - relacje na żywo. Fakt ten wykorzystano w materiałach promocyjnych, pytając retorycznie: „Gdzie będziesz, gdy następnym razem zdarzy się Historia?"62.

Godzic zauważa też, że tematyka, którą podejmowała stacja CNN, znacząco wykraczała poza przyjęte standardy. „Stacja Turnera zaznaczyła swoją odmienność na tle pozostałych także dzięki relacjonowaniu zdarzeń, które w świetle dotychczasowych doświadczeń oraz tzw. kodeksu value news nie stanowiły newsów, czyli zdarzeń szczególnych, które powinny być udostępnione opinii publicznej. Były to relacje z procesów sądowych, nierzadko postaci z półświatka, a więc wydarzenia bliskie określeniu brukowe; były to ponadto nieprzerwane relacje na żywo ze zdarzeń takich jak droga konduktu pogrzebowego ważnej postaci”"63. Turner zmienił oblicze informacji w telewizji, ponieważ znacząco wpłynął na rozumienie tego, co pasuje do newsów. Ze względu na nieprzerwany strumień wiadomości musiały one: „koncentrować się nie tylko na relacjach z pałaców władzy i biznesu, ale także gwiazd show-biznesu oraz - paradoksalnie - życia prostych ludzi" ${ }^{64}$. Rewolucyjne podejście Turnera spotkało się z krytyką. CNN była uważana za producenta zdarzeń na niby (w terminologii Daniela Boorstina) - rocznic i wydarzeń publicznych ważnych tylko dlatego, że biorący w nich udział uważają je za takie. Być może mają rację komentatorzy amerykańskiego życia społecznego, w których opinii to dzięki CNN rozpoczął się proces polegający na zastępowaniu wiedzy przez informację ${ }^{65}$.

Zaproponowany przez Turnera format stacji nadającej na żywo respektował większość przyjętych zasad i norm tworzenia newsów w telewizji. „Czas trwania pojedynczych relacji był bliski dotychczasowym standardom, podobny był też układ - zwykle para prowadzących, zaś w tle reporterzy" ${ }^{66}$. Warto jednak zwrócić uwagę, że „ogromna różnica polegała na traktowaniu publiczności. Była ona zachęcana do interaktywności - już w 1990 roku stacja wprowadziła numer telefoniczny, na który dzwoniąc, widzowie mogli wyrażać swój stosunek do przedstawionych zdarzeń. Prawdziwa rewolucja polegała na zaproponowaniu publiczności innego rodzaju wiadomości, które stały w opozycji do formatu pochodzącego z Public Broadcasting Service, jak i różniły się od ekstremalnego modelu infotainment" ${ }^{\prime \prime}$. Już w roku 1985 działalność rozpoczęła CNN International, oferując wiadomości

61 B. Golka, System medialny Stanów Zjednoczonych, Wydawnictwa Szkolne i Pedagogiczne, Warszawa 2004, s. 64.

62 J. Olędzki, dz. cyt., s. 72.

63 W. Godzic, dz. cyt., s. 80.

64 Tamże.

65 Tamże, s. 80-81.

66 Tamże, s. 80.

67 Tamże. 
z kraju i ze świata. Centra informacyjne rozmieszczono poza Atlantą: w Nowym Jorku, Waszyngtonie, Londynie czy Hongkongu ${ }^{68}$. CNN oferowała także kanał pogodowy, finansowy i sportowy oraz serwis internetowy CNN Interactive, trzy stacje radiowe i 12 witryn internetowych ${ }^{69}$.

Przychody z reklam oraz opłaty subskrypcyjne to główne źródła dochodu CNN. Turner zdecydował jednak nie uzależniać sytuacji finansowej przedsiębiorstwa od reklamodawców ${ }^{70}$. Postanowił wykorzystać rozwój technologiczny. „CNN debiutowało w Internecie w 1995 roku stroną www.cnn.com. Obecnie jest to jedna $\mathrm{z}$ najpopularniejszych stron internetowych. Poza możliwością znalezienia najświeższych informacji, strona oferuje platformę blogową oraz możliwość komentowania tekstów. Od 2005 roku dzięki CNN Pipeline można oglądać za darmo, na żywo aktualne wiadomości. W 2008 roku CNN zostało uhonorowane nagrodą Technology \& Engineering Emmy Awards za nowoczesne rozwiązania technologiczne"71.

CNN jest swoistym synonimem wiarygodnego dziennikarstwa na żywo i bez przerw, ale także synonimem rzeczywistego wpływu mediów na świat ${ }^{72}$. Wpływ ten został zdefiniowany w nauce jako tzw. efekt $\mathrm{CNN}^{73}$. Jednak i ta stacja miała spektakularne wpadki. „Pogoń za sensacją stała się przyczyną wielkiej kompromitacji CNN w 1998 roku. Wówczas przygotowano i wyemitowano głośno zapowiadany reportaż Dolina Śmierci zarzucający rządowi amerykańskiemu popełnienie zbrodni wojennej w Wietnamie - jak się później okazało zupełnie bezpodstawnie. Ten dziennikarski blamaż (nie sprawdzono źródeł informacji) miał wpływ na podważenie autorytetu i wiarygodności stacji”"74. Z perspektywy Polski poważną wpadką było również użycie w 2009 roku przez dziennikarza CNN na antenie określenia „polskie obozy śmierci”. Konieczna była interwencja polskiej ambasady ${ }^{75}$.

Widzowie z całego świata, a zwłaszcza Amerykanie przyzwyczaili się, że „gdy coś się dzieje, należy włączyć CNN"76. Z tego powodu zarządzający stacją CNN nazywają ją crisis-oriented television, czyli telewizją zorientowaną na kryzys. Tylko wydarzenia kryzysowe, katastrofy czy wojny „podnoszą wskaźniki oglądalności, a co za tym idzie zyski stacji z opłat licencyjnych i emitowania reklam. Według

68 Tamże, s. 73.

69 Tamże, s. 72-73.

${ }^{70}$ B. Golka, dz. cyt., s. 65.

${ }^{71}$ K. Potapiuk, Zjawisko foksyfikacji mediów na przykładzie śmierci Kim Dzong Ila relacjonowanej w CNN, „Czasopismo Studenckie Think” 2013, nr 3 (15), s. 15.

72 W. Godzic, dz. cyt., s. 80.

${ }^{73}$ Ł. Kamieński, Technologia i wojna przyszłości. Wokół nuklearnej i informacyjnej rewolucji w sprawach wojskowych, Wydawnictwo Uniwersytetu Jagiellońskiego, Kraków 2009, s. 33.

74 J. Olędzki, dz. cyt., s. 70.

${ }^{75}$ CNN. Legenda pierwszej na świecie telewizji informacyjnej, http://ze-swiata.pl/cnn-legenda-pierwszej-na-swiecie-telewizji-informacyjnej/ (dostęp: 10.09.2017).

${ }^{76}$ M. Talarek, Siła rażenia środków masowego przekazu, CreateSpace Independent Publishing Platform, 2012, s. 143, https://books.google.pl/books?id=Ej_lkQD0BhsC\&printsec=frontcover\&hl= $\mathrm{pl} \# \mathrm{v}=$ onepage \&q\&f=false (dostęp: 17.09.2017). 
gazety »New York Times « w martwym sezonie przeciętny godzinny program ogląda ok. 400 tys. osób. Jednak w przypadku głośnego kryzysu liczba ta sięga dziesiątek milionów"77.

Turnerowi od początku tworzenia CNN, w ramach Turner Broadcasting, przyświecała myśl globalizacji świata. „Jego strategia polegała nie tylko na traktowaniu CNN jako źródła całodobowej informacji ze świata i dla świata, ale na łączeniu dwóch wydawałoby się przeciwstawnych celów: globalizacji i regionalizacji"78. Sam mówił: „CNN to demokratyzacja świata informacji. Po raz pierwszy w historii każdy przywódca i każdy człowiek mają dostęp do tej samej informacji w tym samym czasie"79.

20\% udziałów Turner Broadcasting System (TBS) należało do Time Warner, które ostatecznie w 1996 roku wykupiło CNN. Była to fuzja, która miała doprowadzić do powstania największego koncernu multimedialnego i rozrywkowego na świecie. To połączenie rzeczywiście przyniosło obu przedsiębiorstwom wiele korzyści. Turner zyskał możliwości rozwoju i wsparcie informacyjne takich magazynów jak „Time” czy „Fortune”. W latach 90. mógł z powodzeniem konkurować w dziedzinie ciągłych informacji z Fox News, MSNBC czy BBC World ${ }^{80}$. W roku 1996 Ted Turner przestał być właścicielem Turner Broadcasting, jednak jego rola jako decydenta nie uległa zmniejszeniu. Kwota, za jaką sprzedał pozostałe udziały Time Warner, wynosiła około 3,4 biliona dolarów ${ }^{81}$. Wśród powodów, dla których Turner zdecydował się sprzedać TBS, wymienia się trzy główne: wartość akcji spółki nie rosła na giełdzie, a rozwój i inwestycje związane z CNN przyniosły duży debet; Turner chciał uniemożliwić Murdochowi przejęcie CNN; oraz zawsze chciał połączenia z którąś z wielkich stacji amerykańskich - CBS, NBC lub ABC ${ }^{82}$. Kolejna fuzja, do której doszło w roku 2000, kiedy to Time Warner - wraz z podległym mu CNN - połączył się z America Online, okazała się błędem. Niemniej nic na to nie wskazywało. Miał to być związek tradycyjnych mediów (uosabianych przez Time Warner, bazujących na tworzeniu zawartości) z nowymi mediami (prezentowanymi przez America Online, specjalizującą się w dystrybucji i technologii). Środowisko medialne przyjęło tę fuzję $z$ dużym entuzjazmem ${ }^{83}$. Jej rozpad nastąpił w roku 2009 i mimo wcześniejszego entuzjazmu fuzję AOL z Time Warner okrzyknięto wielkim fiaskiem. Szczególnie nieprzychylnie wypowiadano się o Time Warner, gdyż „decydując się na transakcję, położyli na szali nie tylko pieniądze, ale także swoją reputację, niezależność i wieloletni dorobek”. Rupert Murdoch

77 Tamże, s. 143.

78 B. Golka, dz. cyt., s. 64.

79 Zob. www.medialaw.org/events/55-ted-turner (dostęp: 15.09.2017).

80 B. Golka, dz. cyt., s. 65.

81 Zob. www.ftc.gov/sites/default/files/documents/cases/1997/02/c3709cmp.pdf (dostęp: 15.09.2017).

82 M. Dacko, dz. cyt., s. 72-73.

83 B. Golka, dz. cyt., s. 67. 
skwitował sytuację, w jakiej znalazł się Time Warner, słowami: „oddali firmę za miskę owsianki i muszą z tym jakoś żyć” ${ }^{4}$. Turner z żalem stwierdził, iż „fuzja Time Warner i AOL to był najgorszy dzień w moim życiu" ${ }^{\text {"s }}$.

Ted Turner to jednak nie tylko magnat medialny. Dba o świat i docenia jego piękno - „zakłada rezerwaty przyrody, posiada ponad sto tysięcy morgów terenów, które ma zamiar sukcesywnie powiększać. W kwietniu 1990 roku American Humanist Association ogłosiła go Humanistą Roku, przyznając mu tytuł za wkład w zachowanie pokoju na świecie i ochronę środowiska naturalnego. (...). Niektórzy widzieli w nim kandydata do Nagrody Nobla. Inni - na prezydenta Stanów Zjednoczonych. On sam odrzucał takie pomysły: $O \mathrm{O}$ wiele bardziej interesują mnie problemy całej naszej planety niż tylko jednego kraju""s6.

Turner twierdził, że za pośrednictwem CNN chce pokazać piękno świata: „Zamierzam przemierzyć cały świat, poznać każdą obcą kulturę i przekonać przywódcę każdego kraju, by pokazał mi rzeczy, przez które jest dumny ze swojego kraju. I nadam to wszystko przez satelity ${ }^{87}$. Turner wyrażał się negatywnie na temat broni nuklearnej i niejednokrotnie apelował o pokój na świecie. Mówił: „Już czas zostawić wojnę za sobą. Poczyniliśmy wystarczający rozwój, by powiedzieć wojnie "żegnaj «" ". W spierał rozwój energii słonecznej, argumentując to nie tylko troską o środowisko naturalne, ale także możliwością zdobycia fortuny ${ }^{89}$.

Rupert Murdoch podobnie jak Ted Turner rozpoczął drogę na szczyt od odziedziczenia po ojcu przedsiębiorstwa medialnego. W roku 1953 stał się właścicielem niewielkiego australijskiego dziennika „Adelaide News"90. Wizją Murdocha było stworzenie wielkiego imperium medialnego. Zaprzecza jednak, jakoby wierzył w ideę globalnej wioski i chciał ją tworzyć. Już w 1989 roku tłumaczył, co jest celem News Corp: „Nie ma czegoś takiego jak »globalna wioska«. Większość mediów, przedsiębiorstw medialnych zakorzeniona jest $\mathrm{w}$ ich narodowej i lokalnej kulturze. Niemniej jednak, jeśli zapytacie mnie, czy globalna komunikacja jest możliwa, bez wątpienia odpowiem, że tak. Strategią mojego przedsiębiorstwa jest utrzymanie rozmaitych mediów oddzielnie i czerpanie $\mathrm{z}$ nich zysków na rzecz jednego centrum"91. Ta wypowiedź dowodzi, że misją Murdocha jest zysk, a jeśli strategia globalizacyjna ma mu w tym pomóc, to się nie zawaha. Choć sam nie wierzy

84 M. Dacko, dz. cyt., s. 191.

85 A. Weisman, Ted Turner Reveals His Biggest Business Regret with CNN, http://www.businessinsider.com/ted-turner-wishes-cnn-had-less-fluff-2012-10?IR=T (dostęp: 18.09.2017).

${ }^{86}$ E. Binswanger-Stefańska, CNN - wielka wygrana wizjonera, www.racjonalista.pl/kk.php/s,5894 (dostęp: 4.09.2017).

87 Zob. www.medialaw.org/events/55-ted-turner (dostęp: 15.09.2017).

${ }^{88}$ G. Zapo, Billionaire Ted Turner Shares the Key to His Success, www.inquisitr.com/2306764/ ted-turner-shares-key-to-success (dostęp: 15.09.2017).

89 Tamże.

90 B. Golka, dz. cyt., s. 71.

91 M. Kunczik, Media Giants: Ownership Concentration and Globalisation, Friedrich Ebert Stiftung, Düsseldorf 1997, s. 123. 
w globalizację jako wartość, wielu medioznawców twierdzi, że to właśnie on opracował najlepszy mechanizm dystrybucyjny na skalę całego globu ${ }^{92}$. Stworzona przez niego firma jest przykładem globalnego przedsiębiorstwa medialnego: inwestycje prowadzone przez nią na pięciu kontynentach obejmują gazety, czasopisma, film, telewizję naziemną, kablową i satelitarną, muzykę, branżę wydawniczą, strony internetowe czy sport ${ }^{93}$.

Bartłomiej Golka pisze o Murdochu: „jego olśniewająca kariera skłania do refleksji nad mechanizmami demokracji, umożliwiającymi skupienie w rękach jednostki wręcz niewyobrażalnej potęgi medialnej, czyli zdolności do oddziaływania na umysły ludzkie w skali globalnej" ${ }^{94}$.

W literaturze przedmiotu znajdujemy kilka charakterystycznych etapów ekspansji News Corp ${ }^{95}$. Pierwszym z nich było zwiększenie udziałów spółki na dwóch rynkach: amerykańskim i brytyjskim. W latach 80 . XX wieku Murdoch zdominował rynek prasy dużego formatu i tabloidów w Wielkiej Brytanii. Jego gazety stały się narzędziem poparcia i wyrazem sympatii potentata medialnego do Margaret Thatcher. W zamian za to Murdoch uzyskał poparcie rządu w konflikcie ze związkiem drukarzy. Wtedy to nastąpiło przeniesienie działalności ze słynnego dla prasy rejonu Fleet Street do Wapping. Na początku lat 80. XX wieku Murdoch przyjął obywatelstwo amerykańskie, by uniknąć ograniczeń związanych z własnością zagraniczną - tym samym rozpoczął się drugi etap rozwoju News Corp. Okres ten był związany głównie ze Stanami Zjednoczonymi, gdzie Murdoch poszerza swoją działalność prasową o przemysł filmowy i telewizyjny. Spółka przejmuje dotknięte kryzysem Twentieth Century oraz sieć niezależnych stacji telewizyjnych Metromedia. W roku 1987 Murdoch uruchamia platformę Fox Television Network, której grupą docelową są młodzi odbiorcy. Równolegle na rynku brytyjskim pojawia się telewizja satelitarna Sky Television. Potężne inwestycje w Fox Television Network oraz Sky Television nieomal nie doprowadzają News Corp do bankructwa. Lata 90. to trzeci etap ekspansji. Telewizja Sky łączy się z British Satellite Broadcasting, tworząc BSkyB. Od 1993 roku News Corp dąży do uzyskania znaczącej pozycji w Azji - nabywa spółkę STAR TV z siedzibą w Hongkongu, wchodzi na rynek indyjski i ostatecznie $\mathrm{z}$ wielkim trudem i wieloma ograniczeniami także na rynek chiński. Ostatni etap przyjętej przez Murdocha strategii globalizacyjnej rozpoczyna się udanym przejęciem największego dostawcy telewizji satelitarnej w USA, spółki DirecTV pod koniec 2003 roku $^{96}$. Terry Flew podkreśla, że News Corp udało się stać „silnie

92 Tamże.

93 L. Gorman, D. McLean, Media i społeczeństwo. Wprowadzenie historyczne, przeł. A. Sadza, Wydawnictwo Uniwersytetu Jagiellońskiego, Kraków 2010, s. 311.

94 B. Golka, dz. cyt., s. 71.

95 T. Flew, Media globalne, przeł. M. Lorek, Wydawnictwo Uniwersytetu Jagiellońskiego, Kraków 2010, s. 105-106.

96 Tamże, s. 105-106. 
pionowo zintegrowaną spółką pod względem produkcji i dystrybucji zawartości”"97, a dzięki przejęciu DirecTV mogła niejako otoczyć glob satelitarnym pierścieniem, tworząc Sky Global Network.

Od roku 1995 Murdoch, rozwijając działalność swojej telewizji kablowej, przystępuje do rywalizacji z CNN ${ }^{98}$. Okazuje się, że opracował strategię walki konkurencyjnej: „Fox News w momencie powstania musiał zmierzyć się z silną konkurencją ze strony istniejącej stacji CNN oraz powstałej w tym samym roku NBC. Momentami przełomowymi dla Fox News były afera z Monicą Lewinsky i zamachy z 11 września. Fox News proponowała i nadal proponuje prostą wizję świata, operuje czarno-białą retoryką" ${ }^{99}$. Dzięki przyjętej narracji „ma wielu zwolenników, pomimo krytyki, której jest ustawicznie poddawana"100.

Jednym z powodów założenia Fox, o których mówi sam Murdoch, była chęć stworzenia stacji alternatywnej względem CNN. Zdaniem właściciela News Corp CNN prezentowało poglądy lewicowe, a Fox miał być bardziej obiektywny. Stacja nadaje informacje $\mathrm{z}$ Ameryki i świata, $\mathrm{w}$ formacie całodobowym podobnie jak CNN. Fox News koncentruje się na widowni masowej, lecz ma charakter bardziej lokalny niż CNN, a ostry i prosty komentarz zajmuje miejsce poważnych analiz ${ }^{101}$. „Roger Ailes, prezes Fox News, budował telewizję, kierując się innymi zasadami niż Turner. Dla niego ważniejsze było, kto i jak mówi, od tego, co się mówi. Stawiał na tempo, widowiskowość, niezależnie od tego, o czym była mowa"102. Fox po atakach z 11 września jako pierwsza wykorzystała w czołówce flagę amerykańską. Posługiwała się też hasłem reklamowym: „Informacje uczciwe i wyważone”. Oba te zabiegi miały służyć zwiększeniu oglądalności (a co za tym idzie - zysków ze sprzedaży reklam $)^{103}$. „Kanał mocno akcentował zagrożenie ze strony nie tylko talibów i Iraku, ale również mniejszości narodowych, seksualnych - wszystkiego, co mogło zagrażać ogólnie pojętemu amerykańskiemu konserwatyzmowi. W styczniu 2002 roku Fox miał już większą publiczność niż CNN. Stacja dobrze odczytała potrzeby swych klientów, bo wyrażała to, czego Amerykanie potrzebowali po zamachu na ich wolność: dumę narodową i patriotyzm. Ostra, pełna gniewu, proamerykańska argumentacja musiała przypaść im do gustu, a proste odpowiedzi na trudne pytania ułatwiły kategoryzacje świata"104. Wydarzenia z 11 września 2001 roku stały się dla Fox News pretekstem do medialnej manipulacji. Terminy „wojna z terroryzmem”

97 Tamże, s. 106.

${ }_{98}$ B. Golka, dz. cyt., s. 71.

99 A. Węglińska, Media w sytuacji konfliktu, „Rocznik Bezpieczeństwa Międzynarodowego” 2006, s. 135.

100 Tamże.

101 M. Talarek, Siła rażenia środków masowego przekazu, CreateSpace Independent Publishing Platform, 2012, s. 146, https://books.google.pl/books?id=Ej_lkQD0BhsC\&printsec=frontcover\&hl= $\mathrm{pl} \# \mathrm{v}=$ onepage\&q\&f=false (dostęp: 17.09.2017).

102 Tamże.

103 Tamże.

104 Tamże, s. 148. 
i „terrorysta” były najczęściej słyszanymi słowami w Ameryce. Ten okres aktywności stacji medioznawcy podsumowywali stwierdzeniem: „Ilość kłamstw, jakiej każdego dnia poddany był przeciętny Amerykanin, sprawiła, iż naród ten został po 11 września 2001 r. całkowicie ogłupiony”. Wpływ mediów na opinię publiczną okazał się ogromny, a konsekwencje uwidoczniły się w postawie Amerykanów ${ }^{105}$.

W 2003 roku, po przejęciu platformy cyfrowej DirecTV oraz dokonaniu kilku innych zakupów, Murdoch stał się właścicielem firmy dostarczającej płatną telewizję, wyprzedzając nawet $\mathrm{CNN}$ połączone z Time Warner i AOL ${ }^{106}$. Niemniej stacja Fox w przeciwieństwie do CNN nie uzyskała statusu produktu-marki.

Murdoch deklaruje, że uznaje swobodę - $w$ ramach wytyczonych przez siebie granic - i jest zwolennikiem ścisłej kontroli. Zarzuty o nadmierne ingerowanie w pracę redakcyjną odpiera słowami: „Myślę, że daję moim redaktorom ogromną swobodę. Osoby narzekające, że mają jej za mało, po prostu nie wiedzą, jak ją wykorzystać" ${ }^{107}$. Analiza biznesowej działalności Murdocha wskazuje jednak, iż jego stwierdzenie jest $\mathrm{w}$ istocie paradoksalne. Poważnym naruszeniem granic medialnych i złamaniem zasad rzetelności dziennikarskiej był bowiem słynny skandal podsłuchowy, który rozegrał się w redakcji brytyjskiej gazety „News of the World”. Wiadomym było, że dziennikarze tej gazety pracują w atmosferze konkurencji i presji, czego konsekwencją były działania, które podejmowali ${ }^{108}$. Cały skandal zyskał miano afery Hackgate lub Murdochgate. W wyniku śledztwa podjętego przez Scotland Yard w 2006 roku wyszły na jaw praktyki podsłuchowe dziennikarzy z „News of the World". Ofiarami podsłuchów padły setki osób: sportowcy, celebryci, politycy, rodzina królewska oraz zwykli obywatele ${ }^{109}$. Gazeta „The Guardian” podjęła własne śledztwo ${ }^{110}$. W jego wyniku powstał artykuł opisujący korupcję na szeroką skalę. Aby zatuszować sprawę podsłuchów, policjanci i politycy łącznie mieli otrzymać 100 tysięcy funtów. Ponadto na jaw wyszły nieznane szczegóły porwania i zamordowania trzynastoletniej dziewczynki, Milly Dowler. „The Guardian” odkrył, że dziennikarze "News of the World” nie tylko przechwycili wiadomości z poczty głosowej porwanej dziewczynki, ale też skasowali je z jej komórki. Tym sposobem rodzina Dowlerów miała złudne przekonanie, że Milly nadal żyje ${ }^{111}$. Gwałtowna reakcja opinii publicznej skłoniła Murdocha do działania. Zamknął „News of the World” i oficjalnie przeprosił rodzinę Dowlerów ${ }^{112}$, przekazał im finansowe zadośćuczynienie w wysokości dwóch milionów funtów, a dodatkowy milion przekazał na

105 Tamże, s. 247.

106 B. Golka, dz. cyt., s. 71.

107 Profile: Rupert Murdoch, www.bbc.com/news/uk-14078128 (dostęp: 14.09.2017).

108 R.J. Crawford, Rupert Murdoch and News Corp: The Phone Hacking Scandal, Insead 2014, s. 3, http://centres.insead.edu/social-innovation/what-we-do/documents/INSEADSocialInnovationCentre5947-Rupert_Murdoch-CS-EN-0-04-2014-w.pdf (dostęp: 17.09.2017).

109 Tamże, s. 6.

110 Tamże, s. 7.

111 Tamże, s. 3-7.

112 Tamże, s. 7. 
sześć różnych organizacji charytatywnych ${ }^{113}$. Wydał oficjalne przeprosiny w swoich innych tytułach i jednocześnie stwierdził: „Czuję, że ludzie, którym ufałem (...) zawiedli mnie, i myślę, że zachowali się haniebnie. Czas, by za to zapłacili”114.

Sporny pozostaje jednak rzekomy brak wiedzy o sposobie pracy dziennikarzy „News of the World”. Murdoch jest osobą, która w swoim imperium medialnym decyduje o wszystkim. Jest on postrzegany jako osoba wysoko kontrolująca, która paradoksalnie daje wolną rękę. W przypadku „News of the World” oznaczało to, że nie było potrzeby zlecania przez Murdocha podsłuchów, akceptowania takich działań czy choćby wiedzy o tym, ponieważ jego pracownicy wierzyli, iż właśnie tego się od nich oczekuje. W atmosferze braku potępiania nieetycznych zachowań i zaniżania standardów dziennikarskich redaktorzy $\mathrm{z}$ „News of The World” wiedzieli, że muszą zdobyć niezbędne treści, które się dobrze sprzedadzą ${ }^{115}$. Zeznania świadków potwierdzały, że Murdoch wywiera znaczący wpływ na sposób działania pracowników. Michael Wolff (biograf Murdocha) uważa, że osoba pracująca dla Murdocha w każdej sekundzie myśli o tym, czego oczekuje i pragnie jej przełożony ${ }^{116}$.

Zasadą, której wymaga się od mediów, jest bezstronność polityczna w przekazach informacyjnych. Media mają za zadanie pełnić funkcję kontrolną względem rządów i władz ${ }^{117}$. Tymczasem ostatnie lata wskazują na tendencje częściowej rezygnacji z obiektywizmu na rzecz sympatii politycznych. „Nowością (...) jest zjawisko podążania stacji telewizyjnych tą drogą"118. CNN cieszy się większą popularnością wśród elektoratu Partii Demokratycznej w Stanach Zjednoczonych, zaś stacja Fox News definiowana jest jako konserwatywna i ma większą oglądalność wśród republikanów ${ }^{119}$. Znamienny jest fakt, że każdorazowo w czasie wyborów prezydenckich w USA zwiększa się „rozdźwięk pomiędzy opiniami republikanów i demokratów na temat wiarygodności programów informacyjnych głównych sieci”"120.

Związki Murdocha z polityką są widoczne i między innymi z tego powodu zyskał on status najbardziej kontrowersyjnego magnata medialnego ${ }^{121}$. Na zarzuty o stronniczość i zbytnie zaangażowanie w sprawy polityczne Murdoch otwarcie odpowiedział: „Nie przebyłem całej tej drogi po to, by się nie wtrącać”122. W Wielkiej Brytanii „w połowie lat 90. Murdoch wycofał swoje poparcie dla Partii

113 J. Deans, Phone hacking: Rupert Murdoch is to make a $£ 1 m$ donation to charities selected by the Dowler family, https://www.theguardian.com/media/2011/oct/21/phone-hacking-dowlers (dostęp: 16.09.2017).

${ }_{114}$ R.J. Crawford, dz. cyt., s. 1.

115 N. Craig Smith, Could Your Leadership Style Be Influencing Bad Behaviour?, Insead 2018, s. 2, http://knowledge.insead.edu/node/3638/pdf (dostęp: 19.09.2017).

116 Tamże.

117 W. Stankiewicz, Środki masowego przekazu we współczesnym konflikcie zbrojnym. Casus Iraku w latach 2003-2010, „Zeszyty Naukowe AON” 2013, nr 1 (90), s. 251.

118 Tamże, s. 67.

119 Tamże.

120 Tamże.

${ }^{121}$ L. Gorman, D. McLean, dz. cyt., s. 230.

122 Tamże. 
Konserwatywnej i przerzucił sympatie polityczne na rzecz Partii Pracy Tony’ego Blaira, stwierdziwszy wcześniej, że rząd nowego premiera wykazuje pozytywne nastawienie wobec interesów jego News Corporation" ${ }^{123}$. W 2007 roku, po rezygnacji Blaira ze stanowiska premiera, brytyjska prasa zaczęła spekulować, kiedy Murdoch udzieli wsparcia Davidowi Cameronowi z Partii Konserwatywnej ${ }^{124}$. Warto zauważyć, że polityczne afiliacje Murdocha nie wynikają z ideologii czy stronniczości politycznej, lecz z pobudek biznesowych i ekonomicznych. Dowodzą tego słowa Murdocha w kwestii wsparcia rządów George’a W. Busha w czasie konfliktu w Iraku: „Najlepszą rzeczą, jaka może z tego wyjść dla światowej gospodarki - jeśli można tak powiedzieć - byłoby ustanowienie ceny 20 dolarów za baryłkę ropy. To więcej niż obniżka podatków w jakimkolwiek kraju"125.

Lyn Gorman i David McLean zauważają, że w rzeczywistości zdominowania rynku przez zarządzających, traktujących media „jako narzędzie realizacji własnych, politycznych interesów, w Wielkiej Brytanii ujawnił się, podobnie jak w Stanach Zjednoczonych, konflikt między wymogami rynku a ideałem dziennikarstwa jako służby publicznej. Tak jak za oceanem, ostra konkurencja o pieniądze reklamodawców doprowadziła do przeniesienia nacisku z informacji i tematyki politycznej, społecznej i ekonomicznej na sport, rozrywkę, historie zwykłych ludzi oraz artykuły o stylu życia skierowane do poszczególnych sektorów rynku"126. Takie skupianie się na kulturze popularnej i stylu życia może prowadzić w ich ocenie do przekonania, że nierówności ekonomiczne czy społeczne nie mają znaczenia, a rozwiązaniem wszelkich problemów jest materializm i konsumpcjonizm. Media coraz częściej nie pełnią więc roli niezależnego strażnika i watch doga, wchodzą w sojusze i udzielają wsparcia aktualnie rządzącym, a jedyną ich przesłanką jest wspólny interes, ideologia i zyski ${ }^{127}$. Można zatem stwierdzić, że przedsiębiorstwa medialne są narażone na podwójną kontrolę: polityczną oraz ekonomiczną ${ }^{128}$.

Na charakter przedsiębiorstwa medialnego wpływa z pewnością styl zarządzania, jaki cechuje lidera. Ostatecznie także jego rola i status społeczny, poczucie misji i zaangażowanie. Maria Norbäck zaznacza, że potentaci medialni są czymś więcej niż tylko gwiazdami - są oni aktorami, którzy rozgrywając swoje gry, kreują świat mediów ${ }^{129}$.

123 Tamże.

124 A. Arsenault, M. Castells, Switching Power: Rupert Murdoch and the Global Business of Media, s. 497, http://annenberg.usc.edu/Home/Faculty/Communication/ /media/InternationalSociology.ashx (dostęp: 14.09.2017).

125 Tamże.

126 L. Gorman, D. McLean, dz. cyt., s. 230.

127 Tamże, s. 232.

128 B. Dobek-Ostrowska, Współczesne systemy medialne, [w:] B. Dobek-Ostrowska (red.), Media masowe na świecie. Modele systemów medialnych i ich dynamika rozwojowa, Wydawnictwo Uniwersytetu Wrocławskiego, Wrocław 2007, s. 40.

129 M. Norbäck, The Staging of 'Captain Outrageous versus the Australian Scumbag' - An Analysis of Media Mogul Ted Turner and His Feud with Rupert Murdoch, [w:] L. Küng (red.), Leadership in the Media Industry: Changing Contexts, Emerging Challenges, Jönköping International Business School, Jönköping 2006, s. 195. 
Zarówno Ted Turner, jak i Rupert Murdoch to wyjątkowe osobowości, których cechy znacząco wpływają na rozwój przedsiębiorstw medialnych, których stali się ikonami. To, jak postrzegamy dane media - News Corporation czy CNN - opiera się na opinii o ich słynnych zarządcach. Często jest to efektem wielu zabiegów wizerunkowych i działań fasadowych ${ }^{130}$.

Zdaniem Norbäck, Ted Turner to postać, która kocha być w centrum uwagi i rozwija się, będąc $\mathrm{w}$ świetle reflektorów. Jest niczym performer, aktor, który potrzebuje swojej widowni ${ }^{131}$. Zamiłowanie Turnera do zwyciężania wyraża się w jego własnych słowach: „Nigdy nie rezygnuj. Zwycięzcy nigdy nie rezygnują, a ci, co zrezygnowali, nigdy nie wygrywają"132.

Zarządzanie, które praktykuje Turner, zwane jest przez badaczy przywództwem transformacyjnym. Według Bernarda Bassa transformacyjność definiuje zdolność do zachęcania innych i pociągania za sobą, co zasadniczo zmienia wymiar funkcjonowania przedsiębiorstwa. Zarządzający musi robić coś więcej niż tylko koncentrować się na wymianie dóbr, tworzeniu społeczności czy osiąganiu zysków w sposób zadowalający. $Z$ zarządzaniem transformacyjnym łączy się szczególna cecha liderów, jaką jest charyzma. Zdaniem autora taką charyzmatyczną osobowością jest ekstrawagancki Ted Turner, który przez wiele lat swojej działalności potrafił zaszczepić poczucie misji swoim pracownikom i współpracownikom ${ }^{133}$.

Z kolei Rupert Murdoch to postać kontrowersyjna i trudno pozostać wobec niej obojętnym. Zwykło się mówić, że nad imperium Murdocha „nigdy nie zachodzi słońce" ${ }^{\prime 134}$. Nie ma wątpliwości, że działając na sześciu kontynentach, Murdoch jest jednym z najbardziej skutecznych zarządzających w mediach ${ }^{135}$. Jak pisze Bartłomiej Golka, „Rupert Murdoch jest jednym z najbardziej efektywnych i kontrowersyjnych przedsiębiorców swoich czasów. Ma absolutną władzę nad firmą, a jego rodzina jest jej głównym udziałowcem, kontrolującym 30 proc. biznesu. Jako właściciel największych opiniotwórczych mediów światowych, Rupert Murdoch zyskał miano najbardziej wpływowego człowieka mediów"136.

Michael Kunczik stwierdza wręcz, że gdyby Machiavelli żył w dzisiejszych czasach, z pewnością czytałby Murdocha ${ }^{137}$. Rupert Murdoch to zdaniem autora idealna kombinacja twardego jak kamień przedsiębiorcy, dziennikarza, księgowego

130 Tamże.

131 M. Norbäck, dz. cyt., s. 196.

${ }_{132}$ Zob. www.brainyquote.com/quotes/authors/t/ted_turner.html (dostęp: 14.09.2017).

133 B.M. Bass, From Transactional to Transformational Leadership: Learning to Share the Vision, „Organizational Dynamics” 1990, t. 18, nr 3, s. 25.

${ }_{134}$ Y. Lu, Leadership Analysis of Rupert Murdoch, https://www.academia.edu/6423752/Running_head_LEADERSHIP_ANALYSIS_OF_RUPERT_MURDOCH_Leadership_Analysis_of_Rupert_Murdoch (dostęp: 8.09.2017).

${ }_{135}$ M. Hang, Do Traits Matter? Applying the Leadership Trait Approach to Rupert Murdoch, [w:] L. Küng (red.), Leadership in the Media Industry..., dz. cyt., s. 163.

${ }^{136}$ B. Golka, dz. cyt.; M. Kunczik, dz. cyt., s. 1.

137 Tamże, s. 103. 
i gracza. Z jednej strony jest przedstawiany jako genialny potentat medialny z talentem i gotowością do podejmowania ryzyka, z drugiej zaś jawi się jako krwiożerczy kapitalista, biznesmen bez skrupułów, mroczny typ ${ }^{138}$.

Widoczne są związki Murdocha $\mathrm{z}$ myślą przewodnią prezentowaną $\mathrm{w}$ dziele Machiavellego: „Ktokolwiek pragnie ciągłego sukcesu, ten musi dostosowywać swoje zachowanie do panujących"139. Poparciem tezy o makiawelicznym sposobie zarządzania przez Murdocha są również opinie bliskich mu współpracowników. Twierdzą oni, że gdyby Murdochowi miała towarzyszyć jakaś ideologia, byłoby to pytanie: „Co jest najlepsze dla mnie?”140. Sam magnat medialny podkreśla: „Biznes to wojna, zwycięstwo jest tym, co się liczy"141. Takie podejście do zarządzania w połączeniu z wysoką motywacją dowodzi istnienia prawdziwie makiawelicznego rysu w charakterze Murdocha. Tak silne zorientowanie na wygraną, na osiągnięcie zamierzonych celów prowadzi do konstatacji, że ani etyka dziennikarska czy zawodowa, ani obyczaje społeczne nie są go w stanie powstrzymać142.

Można uznać, iż zarówno Ted Turner, jak i Rupert Murdoch posiadają wizje, które w zadecydowanej mierze konsekwentnie wprowadzali w swoich przedsiębiorstwach. Turner uczynił globalizację najważniejszą ideą, zaś Murdoch chciał osiągnąć maksymalne zyski, władzę i wpływy. Społeczna i etyczna odpowiedzialność to również kwestia, która w sposób widoczny oddziałuje na różnice między Turnerem i Murdochem. Turner przez lata swojej medialnej działalności zyskał miano filantropa - dotował hojnie liczne fundacje, założył własne, wspierał działania na rzecz edukacji, poprawy życia najbiedniejszych oraz ochrony środowiska i pokoju na świecie. Zdobył wiele nagród i odznaczeń. Murdoch przeciwnie - nie zasłynął z powodu działalności charytatywnej, a jedynie z wypłacania odszkodowań po różnych skandalach, które wybuchały w jego firmach.

Teda Turnera i Ruperta Murdocha łączy fakt, że są oni ikonami, twarzami swoich mediów. Obaj odziedziczyli niewielkie firmy i własnymi siłami stworzyli znane międzynarodowe przedsiębiorstwa medialne. Każdy z nich zasłynął z zamiłowania do ryzyka. Murdoch twierdzi, że „tyle w życiu osiągnął właśnie dzięki podejmowaniu ryzyka i łamaniu przyjętych konwencji”, zaś Turner podkreśla: „Jeśli zamierzasz zmienić świat w wielkim stylu, musisz być gotowy dążyć do tego na przekór wszystkim i poświęcić wszystko" ${ }^{143}$. Zdaje się zatem, że ryzykanctwo jest ich cechą wspólną ${ }^{144}$.

138 Tamże, s. 103-104.

139 J. Shafer, The leadership lessons of Chairman Rupert, Reuters, 26.06.2012, http://blogs.reuters.com/jackshafer/2012/06/26/the-leadership-lessons-of-chairman-rupert (dostęp: 13.09.2017).

140 Tamże.

${ }^{141}$ Tamże.

142 Tamże, s. 163.

${ }^{143}$ L. Küng, Strategic Leadership in the Media Industry, The Ashridge Journal, Autumn 2007, s. 7, www.ashridge.org.uk/getmedia/27e662f7-01c6-4231-8aac-f607a7e3dde9/360_Autumn_2007. pdf?ext=.pdf (dostęp: 14.09.2017).

144 Tamże. 
Styl zarządzania, który reprezentują, jest charyzmatyczny i wizjonerski. O obu mówi się, że są liderami transformacyjnymi śmiało patrzącymi w przyszłość. Niemniej Murdoch wybrał zarządzanie oparte na pełnej kontroli i swoistej autorytarności, natomiast Turner - mimo podejmowania ważnych decyzji samodzielnie - osiągnął ogólny poziom kontroli nie przez osobiste angażowanie się w pracę podległych mu pracowników, lecz poprzez wpojenie im silnego poczucia misji i wspólnych wartości.

\section{Podsumowanie}

Podstawowym uwarunkowaniem komunikacji medialnej jest człowiek jako wolny, rozumny i osobowy podmiot. Uznaje się jednak, iż w branży medialnej nastąpiło istotne przeniesienie akcentów - z celu na środki, którymi cel jest osiągany. Hanna Arendt pisze wręcz: „Człowiek społeczeństwa masowego nie potrzebuje kultury, ale rozrywki, a towary oferowane przez przemysł rozrywkowy są przez to społeczeństwo konsumowane, a więc po prostu niszczone"145. Z kolei Bogusław Nierenberg wskazuje, że „współczesne media korzystają z każdej przewagi konkurencyjnej, by pokonać rywali i zdobyć kolejnych odbiorców"146.

Można uznać, że jednym z najważniejszych współczesnych wyzwań w zarządzaniu mediami jest taki stan, by zawartość medialna spełniała jednocześnie dwa kryteria: była interesująca dla odbiorców oraz porządkowała rzeczywistość i nie przekraczała uniwersalnie przyjętych granic etycznych. Praktyka dowodzi jednak, iż etyka, „jak długo jej zasady odbijają się w codziennych relacjach ludzi (a więc też firm i instytucji), wydaje się nie istnieć w świadomości powszechnej. Dopiero jej brak staje się zauważalny i wywołuje reakcje" ${ }^{147}$. Taka tendencja niesie ze sobą konkretne zadania dla osób zarządzających mediami. Ale refleksja dotycząca etyki w zarządzaniu medialnym jawi nam się bardziej jako marzenie niż cel, do którego dążą menedżerowie. To, co można współcześnie obserwować, dalekie jest bowiem od idealistycznych postulatów. „W coraz większym stopniu mamy do czynienia z uniformizacją stylu i treści mediów. Dzieje się tak oczywiście z powodu dominacji na świecie wielkich korporacji amerykańskich. (...). Wszyscy dostają więc te same wiadomości, przekazywane - z małymi różnicami - przez wielkie organy prasowe i stacje telewizyjne w całych Stanach" ${ }^{148}$. Te negatywne konsekwencje globalizacji mediów odczuwają jednakowo wszyscy na całym świecie - „wbrew temu, co myślimy, spustoszenia spowodowane globalizacją bynajmniej nie są li tylko wyra-

${ }^{145}$ H. Arendt, Między czasem minionym a przyszłym, przeł. M. Godyń, W. Madej, Fundacja Aletheia, Warszawa 1994, s. 242.

${ }^{146}$ B. Nierenberg, dz. cyt., s. 128.

147 W. Gasparski, A. Lewicka-Strzałecka, I. Kuraszko, D. Bąk, B. Rok, dz. cyt., s. 144.

148 B. Margueritte, W poszukiwaniu misji mediów, [w:] M. Bonikowska (red.), Media a wyzwania XXI wieku, Wydawnictwo Trio, Warszawa 2009, s. 251. 
zem chęci amerykańskiej dominacji na świecie, ale są odczuwalne również przez samych Amerykanów"149.

Jednakże media, przy całej ich „negatywnej” ocenie, gromadzą różnorakie informacje, które następnie rozpowszechniają przez wciąż rosnącą sieć kanałów dystrybucji ${ }^{150}$. Są więc skutecznym narzędziem komunikacji. Przywodzi to na myśl Heideggerowską koncepcję narzędzia, które realizuje się w czynności używania go: „Wbijanie gwoździ samo odkrywa specyficzną »dogodność młotka« - ale ostatecznie eksponuje się wraz z oplatającą go siecią znaczeń, dopiero gdy młotek z jakiejś przyczyny nie nadaje się już do wbijania gwoździ"151. Stosowalność mediów jako narzędzi, w myśl tej koncepcji, opleciona jest siecią znaczeń. Nie oznacza to jednak, że ich pole istnieje w sposób obiektywny czy absolutny, a jedynie, że stanowi model pozwalający na opis interesujących właściwości ${ }^{152}$. W modelu tym coraz mniej miejsca jest na etykę - na co wskazuje praktyka działania mediów. Warto w tym momencie przywołać słowa Immanuela Kanta: „Postępuj tylko według takiej maksymy, dzięki której możesz zarazem chcieć, żeby stała się powszechnym prawem”"153. Kant, wywodząc absolutny zakaz kłamstwa, nie akceptował żadnych „okoliczności łagodzących”. Masowe kłamstwo nie może stać się prawem powszechnym, stwierdzał, dlatego nie można również dopuścić kłamstwa w przypadkach szczególnych ${ }^{154}$. Dziennikarze i ich szefowie powinni więc być niczym Kant, a często są jak jego mroczny sobowtór - markiz de Sade ${ }^{155}$.

Reasumując powyższe rozważania, warto przytoczyć słowa Macieja Mrozowskiego, który zauważa, że „globalna ocena efektywności działań i wpływu doktryny odpowiedzialności społecznej na praktykę komunikowania masowego jest praktycznie niewykonalna. Można tylko stwierdzić, iż wiele przykładów świadczy o jej inspirującym wpływie na praktykę (...). Z drugiej strony nasilająca się komercjalizacja mediów i wypieranie poważnych treści przez rozrywkę, zwłaszcza rosnąca popularność dziennikarstwa tabloidowego i formatów typu infotainment, zdaje się świadczyć o głębokim regresie etosu odpowiedzialności społecznej mediów"156. Autor podkreśla jednak, że nawet pesymistyczne oceny działania przedsiębiorstw medialnych nie podważają w najmniejszym stopniu zasadności założeń i postulatów koncepcji społecznej odpowiedzialności mediów ${ }^{157}$. Rosnące przekonanie

149 Tamże.

150 M. Mrozowski, dz. cyt., s. 25.

151 M. Heidegger, Bycie i czas, przeł. B. Baran, Wydawnictwo Naukowe PWN, Warszawa 2004, S. 88 .

152 Zob. www.racjonalista.pl/kk.php/ (dostęp: 11.02.2017).

153 I. Kant, Uzasadnienie metafizyki moralności, przeł. M. Wartenberg, PWN, Warszawa 1971, s. $50-51$.

154 Tamże, s. 39-40.

155 Zob. http://www.misilo.pl/images/pdf/Etyka_w_polskich_mediach_ethics_mortuus.pdf (dostęp: 23.12.2017).

156 M. Mrozowski, dz. cyt., s. 206.

157 Tamże. 
o tym, że należy i warto „budować wokół mediów taki klimat i system nacisków, które będą wymuszać na nich dobrowolne respektowanie zasad społecznej odpowiedzialności, wynika z innego, bardziej fundamentalnego przekonania, iż doktryna społecznej odpowiedzialności najbliższa jest ideałowi mediów jako niezależnego pośrednika w stosunkach władzy między systemem społecznym i światem życia odbiorców. Jest to kardynalny warunek demokracji politycznej i społecznej”"158.

W tym kontekście warto zwrócić uwagę na ogromną społeczną potrzebę „ładu, poczucia bezpieczeństwa, wiary w stałe i niezmienne wartości. Chcemy, by świat wokół nas był przewidywalny, sensowny i przyjazny, występuje więc wielka potrzeba etyki, czyli - mówiąc językiem ekonomicznym - popytu"159.

Niniejszy artykuł jest $\mathrm{w}$ istocie przyczynkiem do dalszych badań dotyczących również polskiego rynku mediów. Nadawca publiczny TVP uruchomił szkolenia z zakresu etyki zawodowej dla dziennikarzy redakcji informacyjnych i publicystycznych. Okazuje się, że jako przykłady nierzetelności prezentowane są materiały Faktów i TVN24. Słynnym „paskom” z TVP Info nie poświęca się uwagi ${ }^{160}$. Krytycznie zaś pisze się o nich na przykład w mediach społecznościowych: „Kompromitacja i zaprzeczenie dziennikarstwa. Grzech bez rozgrzeszenia” (Tomasz Zimoch); „To, jak szmacicie reputację mediów publicznych i godność dziennikarstwa, przejdzie do historii” (Łukasz Rogojsz z „Newsweek Polska”); „Głupi jak pasek w TVP Info” (Wojciech Szacki, „Polityka Insight”). Nawet Wojciech Wybranowski z tygodnika „Do Rzeczy” nie znajduje nic na ich obronę: „To, jak wyglądają belki w TVP Info, jest odzwierciedleniem sytuacji w całej stacji. Często jak na to patrzę, mam wrażenie, że ludzie odpowiadający za ten kanał nie mają nic wspólnego z dziennikarstwem, a zwłaszcza informacyjnym"161. Jest to tym bardziej istotne, że w ocenie Denisa McQuaila nadawcy publiczni wciąż uważani są za jeden z niewielu sposobów obrony przed niedoskonałością rynków medialnych ${ }^{162}$. Twierdzi on, że wolny rynek pozostawiony samemu sobie nie spełniłby kryteriów służących realizacji służby publicznej. Ale to już zupełnie inne zagadnienie, które być może stanie się przedmiotem kolejnych badań i analiz.

158 Tamże.

159 Tamże, s. 146.

160 Zob. http://www.newsweek.pl/polska/polityka/tvp-uczy-dziennikarzy-etyki-przyklady-nierzetelnosci-na-pewno-nie-paski-tvp-info,artykuly,419111,1.html (dostęp: 23.12.2017).

161 G. Sajór, Głupi jak pasek, „Press”, 9.10.2017, s. 38.

162 D. McQuail, Teoria komunikowania masowego, przeł. M. Bucholc, A. Szulżycka, Wydawnictwo Naukowe PWN, Warszawa 2007, s. 192-193. 


\section{Bibliografia}

Arendt H., Między czasem minionym a przyszłym, przeł. M. Godyń, W. Madej, Fundacja Aletheia, Warszawa 1994.

Bass B.M., From Transactional to Transformational Leadership: Learning to Share the Vision, „Organizational Dynamics” 1990, t. 18, nr 3.

Blair T., Lecture by the Prime Minister the Right Honourable Tony Blair, MP, on Public Life, Reuters, Canary Wharf, London 2007.

Cavallin J., Democracy, Free Market, Human Rights, [w:] Wolne media dla Europy, Centrum Monitoringu i Wolności Prasy, Kraków 1993.

Czuba K., Media i władza, Ad Astra, Warszawa 1995.

Dacko M., Wielkie fiasko. Fuzja AOL i Time Warner. Studium przypadku, Wydawnictwa Akademickie i Profesjonalne, Warszawa 2007.

Dobek-Ostrowska B., Współczesne systemy medialne, [w:] B. Dobek-Ostrowska (red.), Media masowe na świecie. Modele systemów medialnych i ich dynamika rozwojowa, Wydawnictwo Uniwersytetu Wrocławskiego, Wrocław 2007.

Drucker P.F., Menedżer skuteczny, przeł. J. Górski, J. Szyfter, Wydawnictwo MT Biznes Sp. z o.o., Warszawa 2004.

Drucker, P. F., Zarządzanie w czasach burzliwych, przeł. J. Kajdy, Wydawnictwo Akademii Ekonomicznej, Kraków 1995.

Eco U., Semiologia życia codziennego, przeł. P. Salwa, J. Ugniewska, Czytelnik, Warszawa 1999.

Flew T., Media globalne, przeł. M. Lorek, Wydawnictwo Uniwersytetu Jagiellońskiego, Kraków 2010.

Gałkowski J.W., Zasady etyki zawodowej - etyka biznesu, [w:] M. Borkowska, J.W. Gałkowski (red.), Etyka w biznesie, Towarzystwo Naukowe Katolickiego Uniwersytetu Lubelskiego, Lublin 2002.

Gasparski W., Kodeksy i programy etyczne, [w:] W. Gasparski (red.), Biznes, etyka, odpowiedzialność, Wydawnictwo Naukowe PWN, Warszawa 2012.

Gasparski W., Lewicka-Strzałecka A., Kuraszko I., Bąk D., Rok B., Wolność czy swawola?, „Management and Business Administration. Central Europe” 2011, nr 19/5.

Gąsowska M.K., Kluczowe wyzwania wspótczesnych menedżerów logistyki, „Przedsiębiorczość i Zarządzanie" 2013, t. 14, z. 12, cz. II.

Godzic W., Telewizja - najważniejsze medium XX wieku, [w:] W. Godzic (red.), Media audiowizualne. Podręcznik akademicki, Wydawnictwa Akademickie i Profesjonalne, Warszawa 2010.

Golka B., System medialny Stanów Zjednoczonych, Wydawnictwa Szkolne i Pedagogiczne, Warszawa 2004.

Gorman L., McLean D., Media i społeczeństwo. Wprowadzenie historyczne, przeł. A. Sadza, Wydawnictwo Uniwersytetu Jagiellońskiego, Kraków 2010.

Heidegger M., Bycie i czas, przeł. B. Baran, Wydawnictwo Naukowe PWN, Warszawa 2004.

Hang M., Do Traits Matter? Applying the Leadership Trait Approach to Rupert Murdoch, [w:] L. Küng (red.), Leadership in the Media Industry: Changing Contexts, Emerging Challenges, Jönköping International Business School, Jönköping 2006.

Inderjit S., Media na świecie, [w:] M. Bonikowska (red.), Media a wyzwania XXI wieku, Wydawnictwo Trio, Warszawa 2009.

Jaskiernia A., Czynniki oddziałujące na zachowania mediów masowych $w$ procesach wyborczych, [w:] M. Szpunar (red.), Media - między władza a społeczeństwem, Wydawnictwo Wyższej Szkoły Informatyki i Zarządzania w Rzeszowie, Rzeszów 2007. 
Jenkins H., Kultura konwergencji. Zderzenie starych i nowych mediów, przeł. M. Bernatowicz, M. Filiciak, Wydawnictwa Akademickie i Profesjonalne, Warszawa 2007.

Juszczyk S., Człowiek w świecie elektronicznych mediów - szanse i zagrożenia, Wydawnictwo Uniwersytetu Śląskiego, Katowice 2000.

Kamieński Ł., Technologia $i$ wojna przyszłości. Wokót nuklearnej i informacyjnej rewolucji w sprawach wojskowych, Wydawnictwo Uniwersytetu Jagiellońskiego, Kraków 2009.

Kant I., Uzasadnienie metafizyki moralności, przeł. M. Wartenberg, PWN, Warszawa 1971.

Karwat M., O wymuszeniu medialnym, [w:] M. Duczmal, B. Nierenberg (red.), Media elektroniczne w procesie komunikacji rynkowej, Wydawnictwo Wyższej Szkoły Zarządzania i Administracji w Opolu, Opole 2005.

Kostera M., Koźmiński A.K., Wartości i normy w zarządzaniu. Cztery teatry, [w:] J. Dietl, W. Gasparski (red.), Etyka biznesu, Wydawnictwo Wyższej Szkoły Przedsiębiorczości i Zarządzania im. L. Koźmińskiego, Warszawa 2002.

Koźmiński A.K., Piotrowski W. (red.), Zarządzanie. Teoria i praktyka, Wydawnictwo Naukowe PWN, Warszawa 1997.

Kowalski T., Między twórczościa a biznesem. Wprowadzenie do zarządzania w mediach $i$ rozrywce, Wydawnictwa Akademickie i Profesjonalne, Warszawa 2008.

Kunczik M., Media Giants: Ownership Concentration and Globalisation, Friedrich Ebert Stiftung, Düsseldorf 1997.

Kuraszko I., Etyka przywództwa: dlaczego, jak i gdzie idziemy?, [w:] I. Kuraszko (red.), Etyka przywództwa. Ujęcie interdyscyplinarne, Difin, Warszawa 2014.

Margueritte B., W poszukiwaniu misji mediów, [w:] M. Bonikowska (red.), Media a wyzwania XXI wieku, Wydawnictwo Trio, Warszawa 2009.

McQuail D., Teoria komunikowania masowego, przeł. M. Bucholc, A. Szulżycka, Wydawnictwo Naukowe PWN, Warszawa 2007.

Misztal W., Etyczny wymiar relacji międzyludzkich, [w:] K. Markiewicz, M. Wawer (red.), Problemy społeczne we współczesnych organizacjach, Difin, Warszawa 2005.

Mondy R.W., Holmes R.E., Flippo E.B., Management: Concepts and Practices, Allyn and Bacon, Boston 1983.

Mrozowski M., Media masowe. Władza, rozrywka i biznes, Oficyna Wydawnicza ASPRA-JR, Warszawa 2001.

Łobacz Ł., Telewizja - szanse i zagrożenia wychowawcze, Maternus Media, Tychy 2007.

Nierenberg B., Zarządzanie mediami. Ujęcie systemowe, Wydawnictwo Uniwersytetu Jagiellońskiego, Kraków 2011.

Norbäck M., The Staging of 'Captain Outrageous versus the Australian Scumbag' - An Analysis of Media Mogul Ted Turner and His Feud with Rupert Murdoch, [w:] L. Küng (red.), Leadership in the Media Industry: Changing Contexts, Emerging Challenges, Jönköping International Business School, Jönköping 2006.

Oleksyn T., Zarzadzający i zarzadzanie - wybrane kwestie i dylematy etyczne, [w:] K. Kietliński, V. Martinez Reyes, T. Oleksyn (red.), Etyka w biznesie i zarządzaniu, Oficyna Ekonomiczna Oddział Polskich Wydawnictw Profesjonalnych, Kraków 2005.

Olędzki J., Komunikowanie w świecie, Oficyna Wydawnicza ASPRA-JR, Warszawa 2001.

Picard R.G., Media Economics: Concepts and Issues, Sage Publications, Thousand Oaks, CA 1989.

Pleszczyński J., Etyka dziennikarska i dziennikarstwa, Difin, Warszawa 2015.

Pleszczyński J., Różne rodzaje odpowiedzialności we współczesnych mediach, [w:] K. Wolny-Zmorzyński, M. Wrońska, W. Furman (red.), Między odpowiedzialnościa a sensacją. Dziennikarstwo i edukacja na przełomie wieków, Wydawnictwo Uniwersytetu Rzeszowskiego, Rzeszów 2006. 
Potapiuk K., Zjawisko foksyfikacji mediów na przykładzie śmierci Kim Dzong Ila relacjonowanej w CNN, „Czasopismo Studenckie Think” 2013, nr 3 (15).

Rok B., Czy przywództwo etyczne w działalności gospodarczej jest możliwe?, „Prakseologia” 2009, nr 149.

Różycka M., Zarządzanie zasobami ludzkimi w mediach publicznych. Studium przypadku TVP Katowice, „Zarządzanie Mediami” 2016, t. 4, nr 2.

Sajór G., Głupi jak pasek, „Press”, 9.10.2017.

Stankiewicz W., Środki masowego przekazu we współczesnym konflikcie zbrojnym. Casus Iraku w latach 2003-2010, „Zeszyty Naukowe AON” 2013, nr 1 (90).

Thompson J.B., Media i nowoczesność. Społeczna teoria mediów, przeł. I. Mielnik, Astrum, Wrocław 2006.

Węglińska A., Media w sytuacji konfliktu, „Rocznik Bezpieczeństwa Międzynarodowego” 2006.

Załubski J., Dziennikarz czy media-worker? Ewolucja zawodu, [w:] D. Piontek (red.), W kręgu mediów i polityki, Wydawnictwo Naukowe Uniwersytetu im. Adama Mickiewicza, Poznań 2003.

\section{Źródła internetowe:}

Arsenault A., Castells M., Switching Power: Rupert Murdoch and the Global Business of Media, http://annenberg.usc.edu/Home/Faculty/Communication/ /media/InternationalSociology.ashx.

Binswanger-Stefańska E., CNN - wielka wygrana wizjonera, www.racjonalista.pl/kk.php/s,5894.

Craig Smith N., Could Your Leadership Style Be Influencing Bad Behaviour, http://knowledge. insead.edu/node/3638/pdf.

Crawford R.J., Rupert Murdoch and News Corp: The Phone Hacking Scandal, Insead, 2014, http://centres.insead.edu/social-innovation/what-we-do/documents/INSEADSocialInnovationCentre5947-Rupert_Murdoch-CS-EN-0-04-2014-w.pdf.

Deans J., Phone hacking: Rupert Murdoch is to make a $£ 1 m$ donation to charities selected by the Dowler family, https://www.theguardian.com/media/2011/oct/21/phone-hacking-dowlers.

https://books.google.pl/books?id=Ej_lkQD0BhsC\&printsec $=$ frontcover\&hl=pl\#v=onepage \& $\mathrm{q} \& \mathrm{f}=$ false

http://www.focus.pl/artykul/czym-sie-rozni-etyka-od-moralnosci

http://www.misilo.pl/images/pdf/Etyka_w_polskich_mediach_ethics_mortuus.pdf.

http://www.newsweek.pl/polska/polityka/tvp-uczy-dziennikarzy-etyki-przyklady-nierzetelnosci-na-pewno-nie-paski-tvp-info,artykuly,419111,1.html (dostęp: 23.12.2017)

Kreft J., Multimedia jako cel strategii konwergencji mediów - środowiska komunikacji w biznesie, www.jankreft.pl/pdf/artykuly/Multimedia\%20jako\%20cel\%20strategii\%20konwergencji\%20mediow.pdf.

Küng L., Strategic Leadership in the Media Industry, „The Ashridge Journal”, Autumn 2007, www.ashridge.org.uk/getmedia/27e662f7-01c6-4231-8aac-f607a7e3dde9/360_Autumn_2007.pdf?ext=.pdf.

Lu Y., Leadership Analysis of Rupert Murdoch, https://www.academia.edu/6423752/Running head_LEADERSHIP_ANALYSIS_OF_RUPERT_MURDOCH_Leadership_Analysis_of_ Rupert_Murdoch.

Profile: Rupert Murdoch, www.bbc.com/news/uk-14078128.

Shafer J., The leadership lessons of Chairman Rupert, Reuters, 26.06.2012, http://blogs.reuters. com/jackshafer/2012/06/26/the-leadership-lessons-of-chairman-rupert. 
Talarek M., Siła rażenia środków masowego przekazu, CreateSpace Independent Publishing Platform, 2012, https://books.google.pl/books?id=Ej_lkQD0BhsC\&printsec=frontcover\& $\mathrm{hl}=\mathrm{pl} \# \mathrm{v}=$ onepage $\& \mathrm{q} \& \mathrm{f}=$ false.

Weisman A., Ted Turner Reveals His Biggest Business Regret with CNN. http://www.businessinsider.com/ted-turner-wishes-cnn-had-less-fluff-2012-10?IR=T.

www.racjonalista.pl/kk.php/

www.brainyquote.com/quotes/authors/t/ted_turner.html

www.humanizm.free.ngo.pl/wolenski2.htm

www.medialaw.org/events/55-ted-turner

Zapo G., Billionaire Ted Turner Shares the Key to His Success, www.inquisitr.com/2306764/ted-turner-shares-key-to-success. 